\title{
"humanidades
}

Revista Humanidades

ISSN: 2215-3934

humanidades@ucr.ac.cr

Universidad de Costa Rica

Costa Rica

\section{Imágenes del otro en Brasil. Un análisis comparado de artistas en expediciones}

\author{
Bugnone, Dra. Ana; Capasso, Dra. Verónica \\ Imágenes del otro en Brasil. Un análisis comparado de artistas en expediciones \\ Revista Humanidades, vol. 11, núm. 2, 2021 \\ Universidad de Costa Rica, Costa Rica \\ Disponible en: https://www.redalyc.org/articulo.oa? $\mathrm{id}=498066660008$ \\ DOI: https://doi.org/10.15517/h.v11i2.47315
}

\section{(c) (1) $(9)$}

Esta obra está bajo una Licencia Creative Commons Atribución-NoComercial-SinDerivar 3.0 Internacional, 


\title{
Imágenes del otro en Brasil. Un análisis comparado de artistas en expediciones
}

Images of the Other in Brazil. A Comparative Analysis of Expeditionary Artists

\author{
Dra. Ana Bugnone \\ Instituto de Investigaciones en Humanidades y Ciencias \\ Sociales, Facultad de Humanidades y Ciencias de la \\ Educación, Universidad Nacional de La Plata-CONICET, \\ Argentina \\ abugnone@fahce.unlp.edu.ar \\ (iD) https://orcid.org/0000-0002-6674-717X \\ Dra. Verónica Capasso \\ Instituto de Investigaciones en Humanidades y Ciencias \\ Sociales, Facultad de Humanidades y Ciencias de la \\ Educación, Universidad Nacional de La Plata-CONICET, \\ Argentina \\ vcapasso@fahce.unlp.edu.ar \\ (D) https://orcid.org/0000-0003-3202-4106
}

DOI: https://doi.org/10.15517/h.v11i2.47315

Redalyc: https://www.redalyc.org/articulo.oa?

id $=498066660008$

Recepción: 01 Marzo 2021

Aprobación: 20 Mayo 2021

\section{Resumen:}

Este estudio consiste en un análisis comparativo de las imágenes de indígenas elaboradas en contextos de expediciones realizadas $e^{\circ}{ }^{\circ}$ el nordeste y la Amazonia de Brasil, producidas por el pintor Albert Eckhout (1610-1665) y la artista contemporánea Claudia Andujar (1931-actualidad). Se propone una problematización de la construcción de estas imágenes, a partir de la consideración del contexto de producción, la configuración de los cuerpos, el modo de aproximación hacia el otro, las características y los atributos de las representaciones, los puntos en común y las diferencias entre Andujar y Eckhout. Se empleó una metodología cualitativa desde una perspectiva transdisciplinaria y se basó en el análisis de imágenes en intrínseca relación con su contexto sociohistórico. En este artículo se sostiene que, si bien las producciones artísticas del pintor y la fotógrafa tenían móviles ideológicos y marcos culturales disímiles, la comparación permite abordar de manera conjunta a Eckhout y Andujar en cuanto retrataron sujetos que les resultaban exóticos. Se observó que Eckhout y Andujar trabajaron con la idea de una promesa, en el primer caso, de civilización, y en el segundo, de salvación. Finalmente, se advirtió que, en el marco de la modernidad, la producción de una visualidad de la otredad fue un aspecto central en los dos casos.

PALABRAS CLAVE: Brasil, artes visuales, población indígena, colonialismo.

\section{ABSTRACT:}

This paper consists of a comparative analysis of depictions of indigenous people made in expeditions carried out in the Northeast and Amazonia of Brazil, by painter Albert Eckhout (1610-1665) and contemporary artist Claudia Andujar (1931-nowadays). The goal of this paper is to problematize the construction of these images considering the context of their production, the arrangement of bodies, the way of approaching the other, the characteristics and features of the representations and the (dis)similarities between Andujar and Eckhout. The transdisciplinary method that is used is founded on analysis of images in their historical context. We maintain that, although the artistic work of these artists stem from different ideological and cultural backgrounds, both portray subjects that were exotic to them. It was observed that Eckhout and Andujar worked with the idea of a promise, in the first case, of civilization, and in the second, of salvation. In the framework in modernity, the production of a visuality of otherness was a central aspect in both cases.

KEYWORDS: Brazil, visual art, indigenous peoples, colonialism. 


\section{INTRODUCCIÓN}

Albert Eckhout (1610-1665) fue un pintor viajero holandés que entre 1637 y 1647 vivió en Pernambuco, Brasil, donde retrató su fauna, flora y grupos étnicos, entre ellos, los tupíes y los tapuias ${ }^{1}$. Los trabajos más relevantes sobre el estudio de la producción pictórica de Eckhout (Vries, 2002; Parker, 2006), se han focalizado no solo en la dimensión técnica y estilística de las obras, sino también en el carácter de estas representaciones como 'etnografías visuales' atravesadas por el contexto colonial (Bustamante, 2008). Claudia Andujar (1931-actualidad), por su parte, es una fotógrafa suizo-brasileña que formó parte de una expedición sanitaria a la Amazonia en la década de 1980, donde fotografió a los indígenas yanomamis ${ }^{2}$.

Si bien la comparación entre ambos autores es anacrónica, porque coteja dos tiempos muy distantes, en este artículo se considera productiva para inaugurar nuevas preguntas e hipótesis sobre las imágenes producidas por Eckhout y Andujar. En este sentido, la concepción del historiador del arte Aby Warburg (2010) sobre las obras como documentos abiertos a la interpretación puso de manifiesto la idea de asociarlas a partir de relaciones o de motivos persistentes. Lo anterior permitió realizar comparaciones entre composiciones o ideas, o bien señalar un nexo entre una época y otra desde alguna cuestión específica que, a priori, podría resultar arbitraria (Ruvituso, 2019). Con base en dicha estrategia, en esta investigación se ha construido un corpus de imágenes que forman una serie, la cual considera el planteamiento de Warburg (2010) que, bajo el concepto de 'buena vecindad', da origen a secuencias ${ }^{3}$. (Acuña y Arqueros, 2009).

En la misma línea, Didi-Huberman (2006) explica que el anacronismo es "el modo temporal de expresar la exuberancia, la complejidad, la sobredeterminación de las imágenes” (p. 18). Este aspecto se fundamenta, según el autor, en que en una obra se encuentra "un extraordinario montaje de tiempos heterogéneos que forman anacronismos" (2006, p. 19; cursivas del original). De este modo, conceptos como 'estilo' o 'época' pierden relevancia frente a "los diferenciales de tiempo que operan en cada imagen” (Didi-Huberman, 2006, p. 20; cursivas del original).

A partir de estas definiciones metodológicas, aquí se fundamenta una comparación que parte de aspectos considerados centrales. En primer lugar, Eckhout y Andujar proceden de Europa y realizaron expediciones a Brasil en búsqueda de un encuentro con otros ${ }^{4}$ (en este caso, indígenas); asimismo, en los dos casos produjeron imágenes de las comunidades que visitaron. En segundo lugar, los une el problema del etnocentrismo que emerge en esos encuentros con los otros. En tercer lugar, el pintor y la fotógrafa están atravesados por una característica propia de la modernidad, vinculada con la manera de producir visualidad.

Con respecto al tercer punto, la visualidad implica la producción de un orden y una autoridad a partir de una serie de operaciones: la clasificación según nombres, categorías y definiciones, la separación y la legitimación estética (Mirzoeff, 2016, p. 34). Se considera que este 'complejo de visualidad' (Mirzoeff, 2016, p. 34) opera en Eckhout y Andujar, en cuanto productores de visualidad en la modernidad. Asimismo, es durante ese macroproceso histórico cuando se genera una matriz colonial del poder que implica formas de conocer, de ser, de pensar y de subjetivación que se extienden hasta nuestros días (Mignolo, 2007; Quijano, 2000), aspectos que, más allá de las voluntades, operan también en la producción estética, es decir, las jerarquías conceptuales y sensibles instauradas en la modernidad (Mignolo y Gómez, 2012).

De este modo, se parte de la hipótesis de que, a pesar de los contextos disímiles, al analizar y problematizar la construcción de las imágenes seleccionadas de Eckhout y Andujar, pueden encontrarse puntos en común. En primer lugar, se advierte el énfasis puesto en los cuerpos retratados, tanto en las pinturas como en las fotografías. Así, el cuerpo es representado de distintas maneras, según cada caso, pero la otredad constituye un elemento fundamental de ambos trabajos. En segundo lugar, se observa que el ojo extranjero registró y construyó dichas imágenes desde una dimensión afectiva particular como medio de aproximación al otro (aceptación, rechazo, exotización, etc.). Esto se daba en el marco de móviles ideológicos y culturales que eran disímiles, pero en los dos casos compartían la necesidad de retratar sujetos que les resultaban exóticos. 
En tercer lugar, aquí se sostiene que Eckhout contribuyó a la formación de las imágenes de los indígenas brasileños desde un punto de vista mítico en cuanto a sus características, sus costumbres y sus vínculos con la naturaleza, mientras que Andujar hizo lo propio desde una mirada utópica, basada en la búsqueda de su salvación como comunidad con una cultura conservada casi intacta.

Tanto Eckhout como Andujar compartieron el interés por conocer y registrar las comunidades indígenas con las que se vincularon y lo hicieron a través de una estrategia exotizante. Mientras que Eckhout en su registro tenía como fin el dominio de esas tierras, recursos y cuerpos, Andujar capturó las fotografías en el marco de un profundo proceso de defensa del pueblo yanomami contra el avance territorial por parte de distintas empresas y del Estado. Así, lo que aparece como un registro cuasi policial de algunos miembros de la comunidad yanomami, se trató de un acto de defensa frente a la posible pérdida de sus tierras y, con ellas, su cultura y sus propias vidas.

La selección de las imágenes que conforman el corpus responde al criterio cualitativo de estudio de casos, es decir, a la relevancia y a la especificidad que poseen estas pinturas y fotografías seleccionadas para dar cuenta del problema de investigación planteado. Para analizar las imágenes, se propuso la transdisciplinariedad como estrategia metodológica que incluye el cruce de diversos campos disciplinares, los cuales forman una zona fronteriza para reflexionar en torno al arte (Richard, 2014). Además de utilizar herramientas provenientes de la historia y la antropología, se consideró relevante la perspectiva de la cultura visual, en cuanto concepto y campo de estudios, ya que ofrece herramientas para pensar y comprender el papel de las representaciones visuales del presente y del pasado y las posiciones visualizadoras de los sujetos (Hernández, 2005). Para esta corriente, comprender una manifestación artística supone concebir los repertorios visuales como la puerta de acceso a entramados de sentido, pues el signo es altamente contingente y solo puede comprenderse en su contexto histórico (Mirzoeff, 2003).

Finalmente, el texto se estructura de la siguiente manera: en primer lugar, se presenta el tema, las bases teóricas y metodológicas del estudio; en segundo lugar, se clarifican los conceptos de otro y lo exótico; en tercer lugar, se abordará la biografía de los autores, el contexto de producción, los objetivos de las prácticas y un corpus de obras de Albert Eckhout; luego, se hará lo mismo con la propuesta de Claudia Andujar. En el análisis, se establecerá un diálogo entre las imágenes del pintor y la fotógrafa, teniendo en cuenta las similitudes y las diferencias. Por último, se brindarán las conclusiones.

\section{El otro y lo exótico}

Para el análisis del corpus seleccionado, se acudirá a los conceptos de otro/otredad y lo exótico, así como su relación con los cuerpos y los afectos. Se avanzará brevemente sobre cada uno de ellos con el fin de facilitar la interpretación de las imágenes.

Siguiendo lo que Edward Said ${ }^{5}$. ha denominado 'orientalismo' (2007), puede sostenerse que -sin olvidar las diferencias respecto de Oriente- las representaciones europeas sobre América recaen en la idealización de lo exótico y la exageración de la diferencia. Si bien la obra de este autor refiere únicamente al cercano Oriente, su análisis de la invención europea de un otro oriental puede extrapolarse - mutatis mutandi- hacia otras regiones del mundo, en este caso, América. En la época colonial, la exotización de América fue una manera de retratar a los no europeos como radicalmente distintos, una oposición entre lo civilizado y lo bárbaro. Además, los viajes de los conquistadores hacia América generaron una variedad de discursos en los que se ubicó la figura del otro como sujeto exótico híbrido, dada la superposición del caníbal y del buen salvaje.

Lo exótico es aquello que tiene características diferentes de uno (Todorov, 1991), lo extraño, lo extranjero. Esto puede referir a pueblos, vegetación, fauna y costumbres. Lo exótico puede definirse también como lo no familiar (Boivin, Rosato y Arribas, 2004), a partir de lo cual es posible tomar diversas posturas.

En el caso de la antropología, "frente a lo 'exótico' del objeto, el sujeto que conoce tiene como primera 'sensación' la 'extrañeza', que puede incluir tanto la sorpresa, la rareza e incluso la admiración” (Boivin, Rosato y Arribas, 2004, p. 154). Por otro lado, el exotismo arqueológico se presentó en la literatura como la búsqueda 
de un pueblo remoto y extraño (Grijalva, 2004). La relación entre lo exótico y el otro se basa en que "aquello que es exótico está puesto en el 'otro', está dado en el ser del 'otro'” (Boivin, Rosato y Arribas, 2004, p. 155).

En tanto el término 'identidad' proviene del latín idem, que significa igualdad y continuidad, su contraparte, la palabra otro, se deriva del latín alter, lo distinto, lo diferente. En términos socioantropológicos, no hay producción de una identidad sin un otro que represente lo diferente, lo que no está contenido en ella. La otredad se define, entonces, con base en la diferencia respecto de los otros, quienes son ajenos a nosotros. A esos otros se les atribuyen ciertas características que contrastan con las que conforman una identidad. En esa otredad o alteridad, el otro es tal no como individuo, sino como parte de una sociedad, como portador de una cultura (Krotz, 2004).

El concepto de otredad no necesariamente posee una carga semántica negativa, sino que señala lo diferente tanto en términos sociales como culturales.. Sin embargo, de manera general, la otredad ha operado a través de una inferiorización de aquello que se presenta como desconocido, cuyo ejemplo más claro es la conquista y el genocidio ocurridos en América. El viaje ha sido históricamente la oportunidad para el encuentro cultural con la otredad, también ha representado una ocasión para las conquistas y los imperialismos (Krotz, 2004). Finalmente, es interesante señalar que no hay alteridad sin un cierto grado de etnocentrismo, esto es, que parte de sí mismo para conocer al otro.

En este trabajo, interesa también recuperar el cuerpo como objeto de representaciones simbólicas de la otredad, cuya configuración se establece en relación con el marco histórico-cultural de las imágenes y con las prácticas en las que se inscriben esos cuerpos. De esta manera, si bien en los dos casos que se analizan se trata de cuerpos indígenas, cuerpos otros, estos son representados de distintas maneras según sean las imágenes pictóricas de Eckhout o las fotografías de Andujar. Ahora bien, sobre el contexto de producción de Eckhout, se puede decir que en los siglos XVI y XVII cobró especial interés la atracción por el cuerpo de los otros, por "mostrar la singularidad de otras razas" (Cuartero, 2004, p. 464). En el contexto de la conquista de América, según Toscano López (2017), se desarrolló el 'dispositivo expedición-conquista' como un conjunto de prácticas cuyo papel fue configurar representaciones antagónicas del cuerpo entre el conquistador y el indígena. Si bien este autor se refiere a la conquista de México, se entiende aquí que, en cuanto apunta al 'mecanismo' conformado por prácticas histórico-culturales heterogéneas que hicieron posible distintas representaciones del cuerpo, esta puede ser una categoría aplicable a otros casos de conquista colonial. Como sostiene Toscano López (2017):

La representación del cuerpo del conquistador y del conquistado está mediada históricamente por el choque de dos culturas, de visiones de mundo en conflicto y de cuerpos en tanto fuerzas contrapuestas en pugna y en vías de diferenciación, esto es de autoafirmación de su propia identidad (p. 13).

De esta manera, la generación de repertorios visuales de la conquista y de los tipos sociales identificados por el conquistador son sustanciales en este proceso. Esto no ocurre, como se analizará más adelante, con la forma en la que Andujar trabajó sobre los cuerpos de los yanomamis. Así, más que una representación de conquistador y conquistado, lo que esta artista ofrece es una serie de fotografías que pretenden salvarlos de la occidentalización, aunque esto se realice no sin paradojas, puesto que la propia fotógrafa es suizo-brasileña y no una integrante de la comunidad indígena.

Por último, desde la perspectiva aquí planteada, el arte depende de los dispositivos materiales, simbólicos y emocionales/afectivos particulares de cada cultura además, se relaciona con la existencia común, la circulación de reconocimientos, las identificaciones y los sentimientos (Nancy, 2014). En el campo del arte, se ha vinculado lo afectivo con instancias representacionales ligadas a figuras de lo sublime, lo heroico, lo dramático, lo trágico, lo cómico, lo satírico, entre otros (Moraña, 2012). Aquí, se entiende esta dimensión como medio de conocimiento y de aproximación al otro, y se observan un mayor o un menor grado de exotización. En este sentido, se parte de la definición de Ahmed (2015), quien comprende las emociones en función de cómo moldean cuerpos individuales y colectivos, y las entiende como formas de acción, orientaciones hacia los demás y relaciones que involucran acercamiento o alejamiento. 


\section{Albert Eckhout: un pintor de la corona holandesa en Pernambuco}

En la modernidad, las personas pintoras y viajeras -en su mayoría europeas- a través de sus relatos, informes, mapas e imágenes de América, contribuyeron decididamente a la conformación de las identidades de estas tierras. Produjeron series de paisajes, a veces, acompañados con sus habitantes exóticos en escenas de costumbres o registros etnográficos. En este sentido, el viaje fue, como sostienen Penhos (2005) y Cicerchia (2005), el resultado de la organización de prácticas sociales provenientes del discurso de la modernidad: la expansión, el conocimiento y la dominación. El viaje reflejaba normas, valores e ideologías y estaba diseñado para extender una identidad a través del tiempo y del espacio como un dispositivo de poder. Por su parte, el relato de viaje era una observación disciplinada, una práctica científica y un arte de la descripción, en el cual "el viajero se hacía extraño a los nuevos contextos, y en el tránsito, sus criterios de objetividad se sublimaban. No es parte de lo exótico, pero sí su relator, su juez y su cazador” (Cicerchia, 2005, pp. 13-14).

Siguiendo con lo anterior, los testimonios de personas viajeras se plasmaron en documentos gráficos y pictóricos. Estas representaciones encerraban connotaciones ideales, ya que intentaban encontrar imágenes que, por ejemplo, resumieran las singularidades de la región y aludieran a los personajes más representativos del lugar, es decir, a todo aquello que sirviera para construir la identificación típica de un territorio. Así, los modos de visualidad del territorio explorado y la población americana se asociaron a la dominación tanto material como simbólica y supusieron un recorte en el total de información registrada en las expediciones (Penhos, 2005). Los registros mencionados incluyeron la catalogación de especies vegetales y animales, además de los diferentes pobladores de América. En un principio, estas representaciones conllevaron la construcción de lugares y seres exóticos o curiosos. Luego, "configuraron tipos raciales y sociales característicos, con sus respectivos trajes o vestimentas, usos y costumbres" (Costa, 2015, p. 32).

Albert Eckhout (1610-1665) fue un pintor viajero holandés y uno de los primeros artistas europeos en esbozar este tipo de escenas de América. En 1637 llegó a las costas brasileñas como integrante de la expedición científica y artística de Johan Maurits van Nassau-Siegen, gobernador de las posesiones holandesas en Brasil por la Compañía Holandesa de las Indias Occidentales ${ }^{6}$. Su objetivo fue la documentación minuciosa de la fauna y la flora, de la geografía y de los tipos étnicos del Brasil holandés. El artista permaneció en Pernambuco ${ }^{7}$ hasta 1644 , donde elaboró dibujos, pinturas y grabados.

Los retratos que este autor pintó de los habitantes del nordeste brasileño incluyeron a personas indígenas, mulatas, mestizas y negras. Así, de Albert Eckhout se conoce principalmente un conjunto de veintiún pinturas al óleo sobre motivos brasileños, constituido por los cuatro pares de retratos etnográficos de habitantes de Brasil en el siglo XVII: Homem Tapuia (1643) y Mulher Tapuia (1641), Homem Tupi (1643) y Mulher Tupi (1641), Homem Mulato (ca. 1641-1644) y Mulher Mameluca (1641), Homem Negro y Mulher Negra (1641). A esto se suman una serie de doce naturalezas muertas con frutas y vegetales autóctonos y la pintura Dançados Tapuias (ca. 1640). Estas obras se encuentran actualmente en el Museo Nacional de Dinamarca, en Copenhague.

Como parte de la corte colonial holandesa en Brasil, la obra de Eckhout inaugura un nuevo género pictórico: el retrato etnográfico (Bustamante, 2008). Estas imágenes se caracterizan porque la figura se coloca en el centro, en primer plano y en posición frontal. Sus posturas remiten a retratos europeos de la época. Lo que se destaca en estas pinturas son las características ambientales y los atributos de los personajes. Como se precisará más adelante, en el caso de Andujar, también se recurre al género del retrato, en el que se incluyen la vestimenta, los adornos corporales y las referencias del hábitat, aunque de un modo diferente. En el caso de las imágenes de Eckhout, no solo se propone una identificación de sujetos étnicos, sexualizados y coloniales (que encarnan características de su grupo y, con esto, los homogeneiza), sino también de prácticas culturales consideradas exóticas por los colonizadores (Parker, 2006). Se representan con canastos con frutas y verduras locales, vestimentas y armas con una escenografía compuesta de vegetación y fauna autóctonas, aunque también foráneas. 
Ahora bien, para los fines de este trabajo, se han seleccionado cuatro imágenes de indígenas, caracterizadas por ser descriptivas y naturalistas, en las que se observan algunos de los rasgos mencionados anteriormente. En primer lugar, en la Figura 1, Mulher Tapuia, se observa la representación de una mujer caníbal del grupo tapuia, habitante de las tierras del interior de Brasil que ocupaba un amplio territorio (actualmente, estado de Goiás). La mujer, desnuda, cubierta solo por unas hojas, aparece sosteniendo un brazo humano con su mano derecha y, en el cesto que porta en la espalda, lleva un pie. No está descalza, usa sandalias de fibras vegetales. En la composición, aparece rodeada de vegetación y acompañada por un perro, animal introducido en Brasil por los europeos, lo cual da la idea del contacto entre indígenas y conquistadores. Además, se visualiza un grupo de indígenas armados en el hueco que genera las piernas abiertas de la mujer.

Por su parte, el Homem Tapuia de la Figura 2 también está desnudo y calza un par de sandalias, tiene la cara perforada por dos pinchos y viste un tocado de plumas en la cabeza. En su mano izquierda, tiene una especie de arma hecha de madera y, en la derecha, tiene un lanzador de dardos y flechas. El paisaje es más agreste, con menos vegetación que en las otras pinturas de Eckhout, y muestra animales venenosos: una tarántula y una serpiente. Además, no aparecen indicios de la colonización (como plantaciones y haciendas).

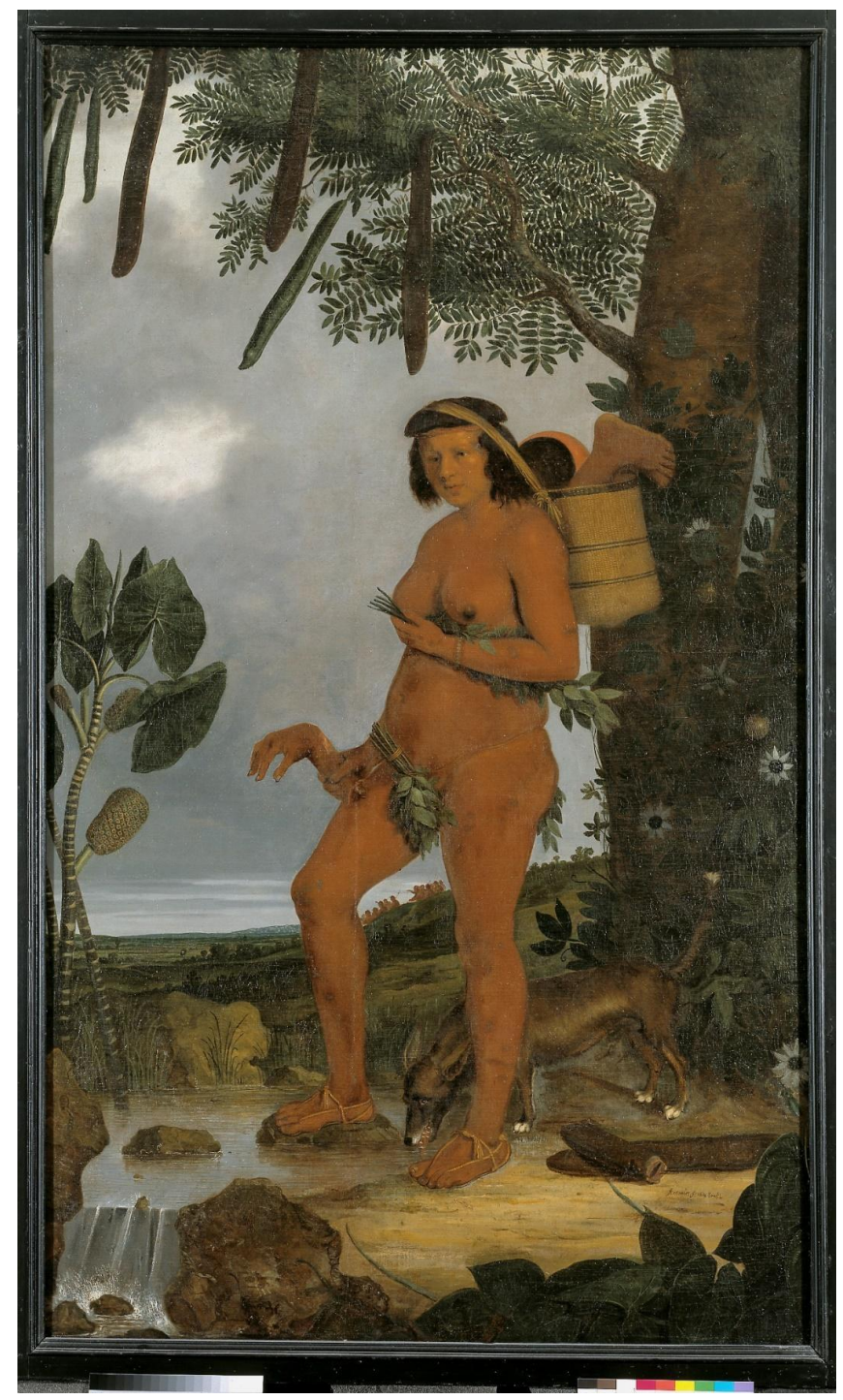

FIGURA 1

Mulher Tapuia, 1641, óleo sobre tela

Fuente: Fotografía de John Lee, National Museum of Denmark ${ }^{8}$ 


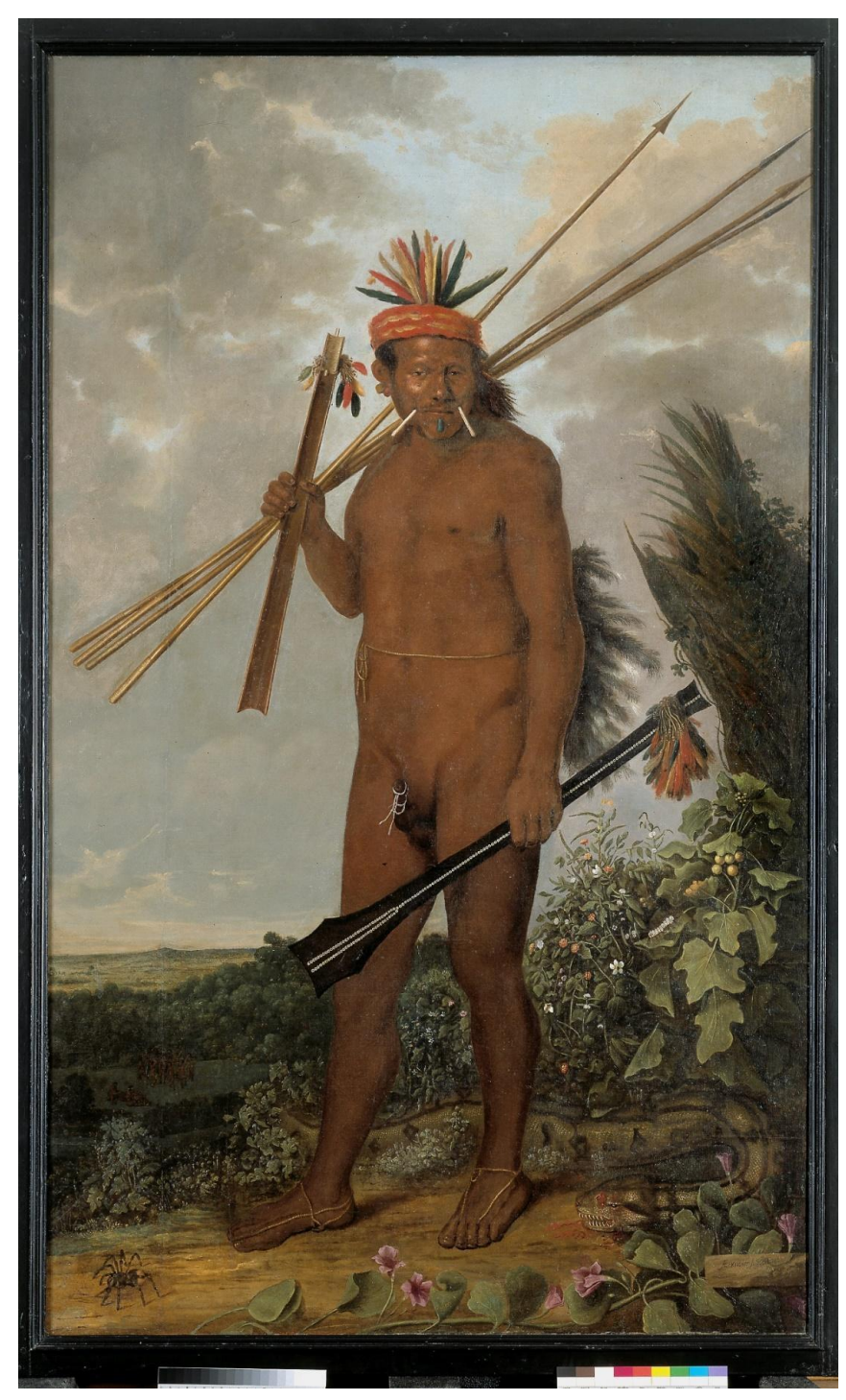

FIGURA 2

Homem Tapuia, 1643, óleo sobre tela

Fuente: Fotografía de John Lee, National Museum of Denmark

En segundo lugar, se presenta a una pareja tupí en las figuras 3 y 4 . Cuando llegaron los portugueses, los pueblos tupíes ocupaban casi toda la costa de Brasil y extensas áreas de la selva amazónica. En la Figura 3, obra denominada Mulher Tupi, se muestra a una mujer de este grupo étnico con los senos desnudos y vistiendo una falda. Con el brazo derecho sostiene a un niño, presumiblemente su hijo, y una calabaza para el agua. Asimismo, con la mano izquierda sostiene una cesta sobre su cabeza que contiene distintas manufacturas. A su derecha hay un banano, fruta foránea introducida en Brasil. A sus pies hay un sapo, autóctono de la zona. Por último, se visualiza en el fondo de la composición un paisaje colonial: una hacienda con una casona y personas trabajando en una plantación (quizá estas eran personas esclavizadas o indígenas).

En la Figura 4, el Homem Tupi, de torso desnudo, descalzo, apenas viste una tela. Lleva un cuchillo en su cintura y sostiene un arco y flechas, símbolos de un guerrero. A sus pies, en el cuadrante inferior derecho, aparece una mandioca cortada al medio. En el fondo de la pintura, se visualiza un río e indígenas bañándose en él. 


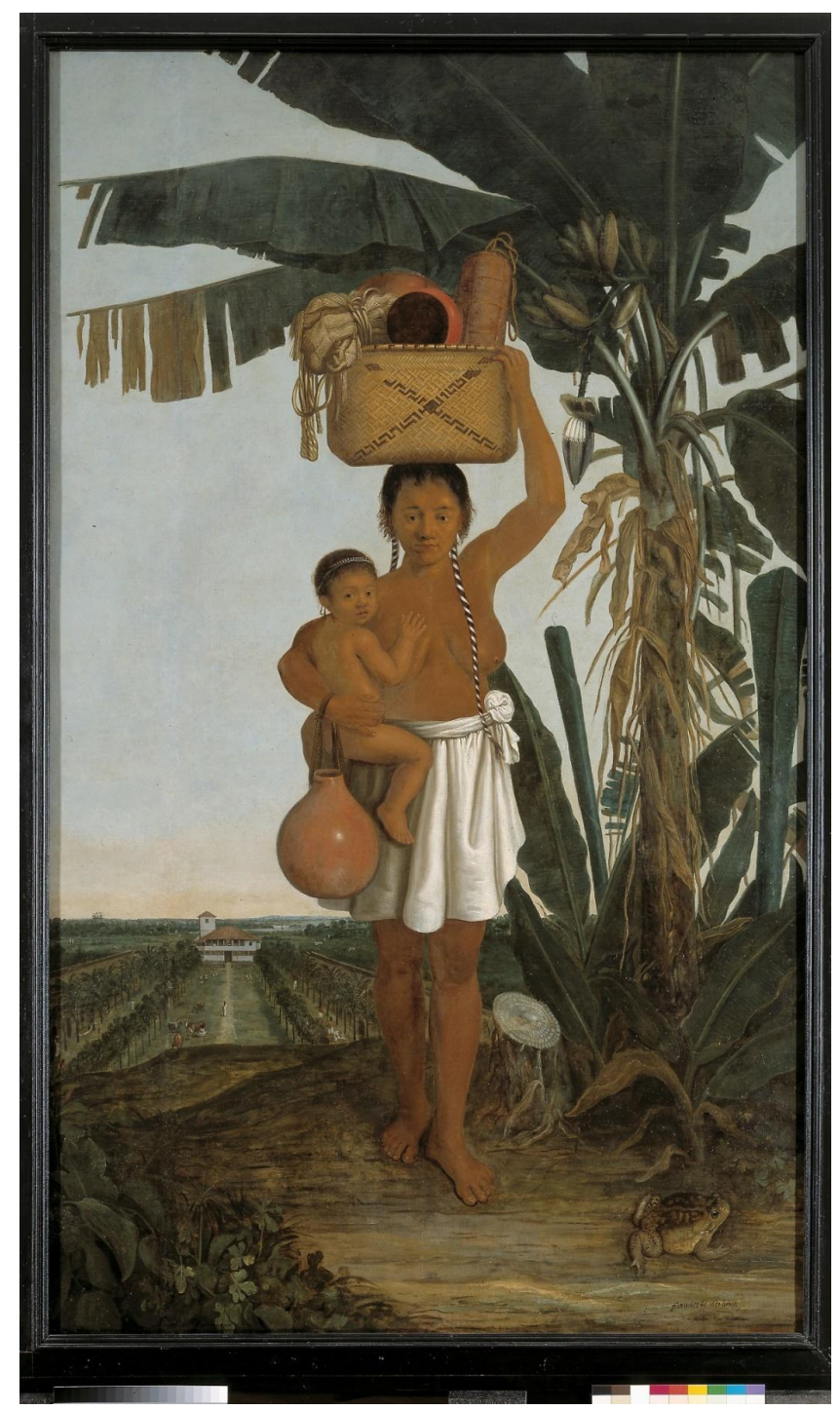

FIGURA 3

Mulher Tupi, 1641, óleo sobre tela

Fuente: Fotografía de John Lee, National Museum of Denmark 


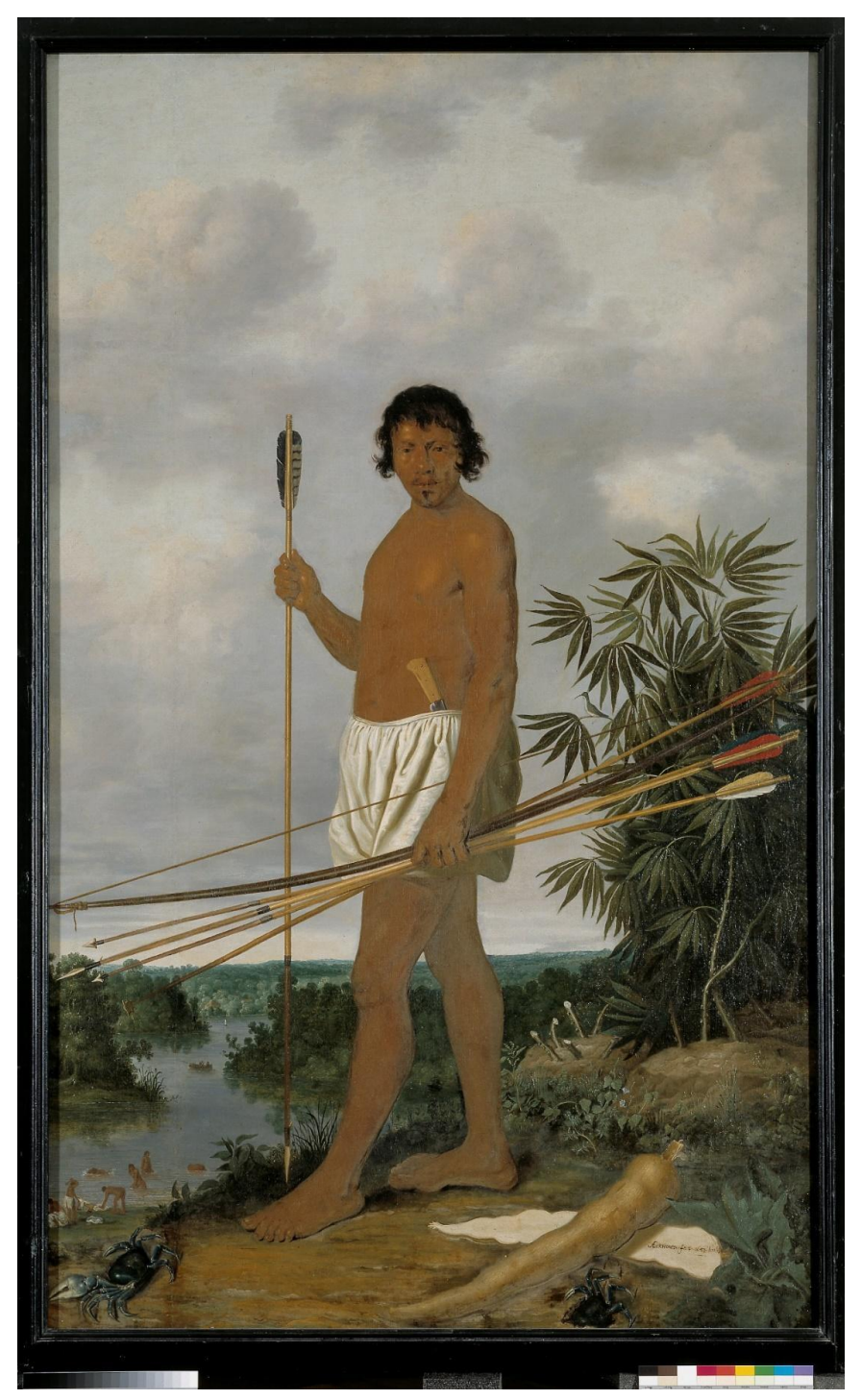

FIGURA 4

Homem Tupi, 1643, óleo sobre tela

Fuente: Fotografía de John Lee. National Museum of Denmark

Cuando se comparan las representaciones de las parejas de tapuias y de tupíes, se observan dos diferencias centrales. En primer lugar, la existencia de un contraste vinculado con los cuerpos y sus atributos: vestidos o desnudos, con armas o pedazos de cuerpos humanos, lo cual parecería dividirlos entre un grupo indígena amigo y bueno (el tupí) y un grupo salvaje y enemigo del colonizador (el tapuia). La división entre amigos y enemigos construye una trama afectiva que delinea un grupo colaborador y otro adversario, lo cual podría dar algunos indicios sobre la estructuración de la sociedad colonial, en las que se configuran relaciones de acercamiento o alejamiento (Ahmed, 2015). Esto quiere decir que, mientras las representaciones de los tupíes muestran modos relacionados con lo que lo conquistadores consideraban civilizado, como es el estar vestido y el vínculo con actividades domésticas, las representaciones de los tapuias se vinculan con rituales antropofágicos y guerreros, modos que representaban lo bárbaro desde la perspectiva de los conquistadores. Si bien ambos grupos étnicos practicaban la antropofagia en situaciones diferentes, Eckhout la asoció solamente al grupo tapuia. Este aspecto no es menor, ya que los colonizadores europeos hicieron de la antropofagia de algunos pueblos americanos un tema central para demostrar su grado de salvajismo; así, acompañaron estas 
ideas con exageraciones y mitificaciones, lo que les permitía asociar a los pueblos indígenas con una cualidad animal.

Finalmente, otro elemento relevante dentro de la representación de los tapuias como seres bárbaros, en comparación con sus coterráneos tupíes, es su completa desnudez. Por otra parte, es interesante contrastar las representaciones del paisaje. En este sentido, mientras que en las pinturas de la mujer y el hombre tapuias estos se muestran en entornos más rústicos, agrestes y con animales salvajes -reforzando así la idea del primitivismo, lo salvaje y lo exótico-, en las que aparece la pareja tupí, ellos se insertan en un paisaje doméstico, modificado por la cultura europea: las plantaciones y la prosperidad agrícola (Chicangana-Bayona, 2008). En el caso de las fotografías de Andujar, no existe esta configuración dicotómica entre un grupo civilizado y otro bárbaro, sino que, tal como se verá en el apartado siguiente, se apela a la representación de individualidades de una misma comunidad. Asimismo, su accionar rompe la distancia con ese otro, se acerca, se involucra y genera un vínculo afectivo en el marco de su defensa.

Con respecto a lo exótico en la producción pictórica de Eckhout, está presente en las descripciones que realizó sobre los pueblos, la vegetación, los animales y las costumbres indígenas, característica común en los registros de las personas viajeras desde que se inició la conquista. Como observó Belluzzo (1994), estos retratos, de cierta forma, brindan más la idea de la dominación holandesa en Brasil que una representación del propio Brasil y exotizan no solo el paisaje silvestre, sino también los cuerpos de los indígenas (Paredes, 2017, p. 63) y sus prácticas. De esta forma, tanto el relato de las personas viajeras como las imágenes producidas en las expediciones eran importantes medios de dominación de los territorios conquistados.

El uso de la visualidad se convirtió, entonces, en un recurso de poder muy utilizado para mapear sus tierras, registrar los productos comercializados e identificar los tipos sociales de América, marcados por tipos negativos (nativos salvajes, bárbaros, enemigos de los europeos) o positivos (o nativos buenos). Con relación a esto último, se podría identificar una gradación evolutiva que va de los tapuias hasta los tupíes, es decir, de lo bárbaro y caníbal a lo civilizado. En la modernidad, con la preeminencia de teorías que abogaban por la existencia de razas superiores e inferiores y con la producción de visualidades que reflejaban estas ideas, los tupíes, comparados con los tapuias, se representaban más distanciados de lo primitivo y salvaje: los cuerpos vestidos y no desnudos, el trabajo artesanal, el habitar espacios domesticados. En contraposición, aparecía lo agreste conjugado con la mitificación de los tapuias, vinculados con el canibalismo, típica representación de los indígenas en Brasil. De esta manera, en las obras de Eckhout, por un lado, aparece una figuración mítica de lo salvaje (tapuia) y, por otro, se ofrece una prefiguración utópica de civilización (tupí).

\section{Claudia Andújar, promesa de contra-conquista}

Claudia Andujar es una fotógrafa nacida en Suiza, pero que vive en Brasil desde los años 50. Ella cuenta que comenzó trabajando como fotógrafa periodística hasta que, en 1971, la revista Realidade produjo una edición especial sobre el Amazonas. A partir del encargo de la revista, Andujar realizó una serie de fotografías que incluía al grupo étnico aharaibus, a pesar de las directivas del gobierno dictatorial de no inmiscuirse con la cuestión indígena debido a intereses particulares sobre el territorio. La fotógrafa relata que, a partir del encuentro con la comunidad yanomami, decidió dejar el fotoperiodismo, conocerla con mayor profundidad y fotografiarla (Pereira, 2015). Vivió con este pueblo entre 1971 y 1977, luego fue expulsada por el Gobierno y la defensa de los yanomamis se transformó en un objetivo de vida.

Este pueblo nómade habita la zona del Amazonas brasileño y venezolano. Andujar se comprometió con la protección de los indígenas a raíz de la amenaza que significaba el avance de la carretera Perimetral Norte sobre su territorio, en los años 70, y la consecuente pérdida que esto representaba, tanto a nivel territorial como cultural. Asimismo, la explotación minera de la zona llevó a la destrucción del entorno con graves resultados en la población. A esto se sumaron las enfermedades traídas por ese contacto. La fotógrafa creó la ONG Comissão pela Criação do Parque Yanomami, luego convertida en la Comissão Pró-Yanomami, para la defensa de este pueblo y, especialmente, para controlar el avance tanto estatal como empresarial y establecer una demarcación de su territorio para que no fuera invadido ni explotado. Entre las acciones que 
emprendieron, organizó una misión de salud con dos médicos para vacunar a las personas pertenecientes a esta etnia y ahondar en su forma de vida. Estos datos fueron publicados con el nombre de Informe 82, elaborado en 1982 para la Comissão Pró Yanomami. En este sentido, comparte con la expedición de Eckhout la implementación del viaje como forma de conocer y describir con imágenes a un pueblo, aunque difieren, claramente, en relación con la búsqueda de dominación, en el caso del holandés, y la expectativa de salvación, en el caso de la fotógrafa.

De esta expedición surgió la serie que luego Andujar llamó Marcados, compuesta por fotografías realizadas entre 1981 y $1983^{9}$. La serie fue expuesta en Brasil, por primera vez, en la vigesimoséptima Bienal de São Paulo: Cómo vivir juntos, en 2006, y, luego, estuvo presente en el Museu de Arte Moderna da Bahia (Salvador), en la Pinacoteca do Estado de São Paulo, en el Instituto Tomie Ohtake (São Paulo), en el Centro Cultural Banco do Brasil, entre otras exposiciones.

Se trata de retratos tomados a personas de diferentes edades, con un número colgado en el cuello. De esta manera, se observa un rectángulo de plástico con números intercambiables que cuelga de un hilo del cuello de cada una de las personas fotografiadas. El uso de números, polémico por cierto, se debía a que necesitaban registrar quién había sido vacunado, ante la dificultad que encontraron para llamarlos de algún modo, ya que entre los yanomamis no existen los nombres propios, sino formas de nombrar que se relacionan con eventos $o$ anécdotas que no permanecen estables.

Según la fotógrafa, la numeración "foi uma tentativa de salvação. Criamos uma nova identidade para eles, sem dúvida, um sistema alheio a sua cultura" (Andujar, 2009, p. 5). Posteriormente, cuando presentó la exposición Marcados, Andujar dijo que presentaba las fotografías para "transformar o simples registro dos yanomami na condição de 'gente' -marcada para viver- em obra que questiona o método de rolutar seres com fins diversos" (Andujar, 2009, p. 5). La referencia al método de rotulación tiene estrecha vinculación con la vida de la artista, cuyos familiares y amigos fueron marcados y asesinados en campos de concentración nazi, donde las marcas, en primera instancia sobre la ropa y, luego, sobre el cuerpo, determinaban la pertenencia al grupo perseguido. De este modo, la artista busca mostrar cómo la rotulación de los cuerpos puede adquirir el sentido contrario al que tuvo en el nazismo: la supervivencia de la comunidad indígena.

En las fotografías, se observan algunas personas desnudas y otras con vestidos occidentales, así como cuerpos pintados y decorados con pinchos. Esta combinación muestra en qué medida estaban incorporando el contacto con la cultura occidental, aunque no plenamente. Sin embargo, los fondos seleccionados por Andujar para tomar estas fotografías, selváticos o sus viviendas, corresponden al espacio habitado por este pueblo, lo que remite a su condición de cultura no conquistada. A diferencia de las pinturas de Eckhout, que separan a los tapuias -etnia vinculada con prácticas salvajes, en cuyas representaciones no hay vestigios del conquistador- de los tupíes -grupo indígena que, por ciertos atributos relacionados con los europeos, respondía mejor a la idea de civilidad-, algunas fotografías de Andujar conjugan elementos occidentales, como la ropa, con espacios no intervenidos por la cultura occidental, sin que con eso se mitifique o pondere un rasgo frente a otro.

La rigidez de las poses y los gestos en las fotos señalan la tensión generada por la situación frente a la cámara fotográfica y, posiblemente, la consulta médica. Si bien en otras fotografías se ven personas más relajadas y dispersas, la condición de la exposición a un objeto extraño como la cámara no deja de ser un síntoma de que el contacto que se quiere evitar es, paradójicamente, parte de la situación provocada por la misión médica y humanitaria que viene a salvarlos tanto de las enfermedades como del avasallamiento territorial, ambos producidos por el encuentro con Occidente.

En la producción fotográfica de Andujar, el componente exótico se manifiesta en el hecho de que las fotografías tomadas, en primer lugar, resultan del contacto con el mundo occidental y del encuentro, a veces por primera vez, con la situación de ser retratados. Sin embargo, cabe señalar que la fotógrafa vivía con la comunidad, formaba parte fundamental de la lucha por la defensa de su territorio y, con él, de su forma de vida. Pero, al mismo tiempo, el propio contacto con la fotógrafa ya implicaba una relación de otredad. 
En estas fotografías se puede observar la centralidad de los cuerpos y los rostros. Los cuerpos no están estereotipados, sino que cada uno de ellos representa una individualidad con sus gestos, rasgos, vestuario y accesorios, a diferencia de las representaciones de Eckhout, quien produce tipos generales que sintetizan los rasgos tapuia y tupí. La numeración sobre los cuerpos de los yanomamis remite a una referencialidad policial o presidiaria, y, con ella, a una idea de control social. Sin embargo, las imágenes que Andujar construyó de los yanomamis no están directamente relacionadas con el imaginario de la conquista, sino más bien con lo opuesto.

Un punto de contacto entre las obras de Eckhout y Andujar con respecto al cuerpo se basa en una paradoja, a pesar de sus fines opuestos: en el contexto de Eckhout, las pinturas de los cuerpos intentan mostrar la otredad, lo mismo ocurre con las fotografías de Andujar. Entonces, aparece aquí lo 'anacrónico' (DidiHuberman, 2006), en cuanto a que en las fotografías se muestra un rasgo anterior, fuera de su tiempo, pero que permaneció en la construcción de las imágenes de los indígenas a partir del mundo colonial de la modernidad y la construcción de la visualidad que trajo aparejada. Este rasgo fue posible porque, en las culturas visuales de ambas épocas (siglos XVII y XX), la forma en la que la otredad indígena fue representada y visualizada no dejó de ser, hasta cierto punto, etnocéntrica.

La fotógrafa propone una relación con los cuerpos que implica dos cuestiones disímiles al mismo tiempo: en primera instancia es un acercamiento; en segundo lugar, una distancia. La fotografía acerca esos cuerpos extraños al mundo occidental -incluso a la propia Andujar-, los rotula para salvarlos, los retrata para identificarlos. En esos retratos, las subjetividades no quedan perdidas, hay singularidades, como menciona Garramuño (2018). Aparecen los signos de las diversas personalidades, los miedos y, posiblemente, el temor a la situación de estar frente a una cámara (Senra, 2009) y los vínculos físicos y afectivos entre madres e hijos, rasgos que caracterizan a esas fotografías de un modo diferente al objetivo original ligado a las prácticas médicas. Aquí, lo afectivo se manifiesta a partir del dispositivo fotográfico, esto es, quien toma la foto se acerca a ese otro y lo afecta al generarle determinadas sensaciones (temor, risa, seriedad, etc.). Lo afectivo está plasmado en las propias representaciones y se vincula, por ejemplo, con expresiones corporales y faciales de las personas fotografiadas. También lo afectivo aparece, como se dijo, en aquellas fotos en las que se visualizan vínculos entre las personas (como madre e hijo que se miran/se tocan). Al mismo tiempo, hay una distancia con relación a esos cuerpos, en la medida en que sus ropas, adornos, posturas, desnudez no son conocidos, no pertenecen a la construcción de los cuerpos occidentales. Son cuerpos otros y esa misma otredad es la condición para su salvación.

Aquí brota, nuevamente, un rasgo de lo anacrónico, en cuanto existen aspectos del discurso colonial que son retomados en las fotografías a partir de la representación de los cuerpos siempre como una otredad. Sin embargo, en el caso de Andujar esa otredad es objeto de un tipo de imagen, donde lo subjetivo no se invalida y cuyo fin es brindar auxilio y no dominación.

Como se dijo anteriormente, el trabajo de Andujar en Marcados presenta una utopía basada en la idea de evitar el avance estatal y empresarial que, en definitiva, es impedir el contacto occidental con el pueblo y su cultura. Este anhelo es también una promesa de restitución de un pasado remoto, un afán contraconquistador, contra-colonizador. Evadir las crueldades que el genocidio europeo había provocado casi cinco siglos antes en América Latina se transformaba en un deseo del presente. Si se vuelve a las pinturas de Eckhout, se puede observar el contraste con los objetivos emprendidos con el proyecto de Andujar; la obra del pintor holandés estuvo sujeta a producir un dominio -vía registro y conocimiento- sobre el territorio y los cuerpos que en este habitaban.

La forma en que esa utopía se plasmó en las imágenes de Andujar se centró en los cuerpos, en la subjetivación de cuerpos retratados que, como sostiene Senra (2009), a pesar de la perturbadora numeración, no han perdido los efectos de lo individual: sus poses, adornos, vestidos alejan la mirada policial del número que marca cada persona. 
Ahora bien, en la utopía de Andujar existe una posición política e ideológica de protección hacia los yanomamis que se plasmó directamente en la institucionalización del reclamo, en una organización específica, cuyas acciones estuvieron coordinadas por la fotógrafa. Esta utopía, además, es una esperanza generada por una persona que no pertenece al grupo, una esperanza foránea. Esta posición de ajenidad -a pesar de haber vivido con este pueblo durante un largo tiempo, la fotógrafa no dejó ser una suizo-brasileña- se vincula con una cierta exotización de los retratados, fijada en la numeración que cada una de las personas porta frente a la imposibilidad de usar sus propias referencias para identificarlas. Es decir, la falta de nombres propios entre el pueblo yanomami no significa la ausencia de formas de referirse a una persona. Es probable que tanto la vaguedad como el carácter efímero de estos nombres hayan dificultado su identificación por parte del grupo de médicos que los estaban asistiendo, pero no implica una ausencia total de posibilidades de usar otros métodos alternativos a la numeración. Es, entonces, esa numeración precisamente la que señala el exotismo en cuanto demuestra la ajenidad en la imposibilidad de nombrar.

\section{Conclusiones}

En el corpus analizado, conformado por obras del pintor Albert Eckhout y de la artista contemporánea Claudia Andujar, se hallaron varios puntos en común y algunas diferencias. Estas coincidencias, surgidas a partir del trabajo en series, llaman la atención porque se producen en contextos históricos diferentes. No obstante, las imágenes de otros indígenas producidas por el holandés y la suiza se ubican en la modernidad como un proceso histórico de producción de visualidad y en cuanto generadora de visualidades clasificadoras y ordenadoras, así como de estéticas coloniales. A lo largo del artículo, se señaló la forma en que estas características aparecen en las imágenes de Eckhout y Andujar, aun cuando las intencionalidades hayan sido divergentes. Seguidamente, se resumen los principales puntos que surgieron del estudio.

Ahora bien, a partir del análisis de las obras, se observó que, en ambos casos, la expedición fue un procedimiento de aproximación al otro, aunque los contextos y objetivos para cada uno hayan sido diferentes. Es decir, la expedición en el caso de Eckhout se vinculó con el contexto de conocimiento vía conquista de tierras, apropiación de recursos y sometimiento de pueblos indígenas. Además, las pinturas se hicieron por encargo con el fin de registrar la flora, la fauna y los tipos sociales. En un principio, estaban destinadas a ser expuestas en la vivienda de Johan Maurits van Nassau-Siegen, por ello, su circulación fue limitada. En oposición, la expedición de Andujar estuvo asociada con fines médicos y de resguardo de las poblaciones indígenas. En este caso, su registro fotográfico, en primera instancia, tuvo un fin sanitario, fue un modo de identificar a las personas de la comunidad que fueron vacunadas. Luego, esas fotografías fueron pensadas como obras y circularon por diversas instituciones artísticas y museos de Brasil y del mundo.

Se realizó una comparación anacrónica, pero se entiende que es productiva, en cuanto permite ver contactos más allá de sus propias épocas, así como observar diferencias y semejanzas que expresan algo más que sus contextos específicos, ya que pueden ser puestas en diálogo en cuanto imágenes que siempre refieren a un otro. A través del análisis, se identifican distintos modos de visualidad, es decir, diferentes significados generados por las imágenes trabajadas, en vinculación con su contexto espacio-temporal y las estructuras sociales, políticas y culturales con las que se asocian.

En cuanto a los registros realizados por Eckhout y Andujar, mientras las representaciones del primero homogeneizaron las características de las etnias tupí y tapuia, al sintetizar atributos a partir de la representación del hombre y la mujer de cada grupo, las fotografías de la segunda produjeron un registro numérico de cada persona, condicionado por el objetivo médico de la expedición, con el fin de atender a cada individualidad. Es decir, la operación ha sido a la inversa. Sin embargo, hay un punto de contacto en ambos tipos de registro: el uso del retrato como el género que permite dar cuenta de posturas corporales y modos del cuerpo, vestimenta y atributos del retratado, lo cual puede dar indicios de pertenencia social y elementos de distinción. Además, en los dos casos hay un acercamiento a cuerpos otros, exóticos, que no se corresponden con los cuerpos hegemónicos de ambas épocas. 
Como se analizó, en las imágenes que expresan ambas expediciones, hay una centralidad del problema del contacto, de la relación con el otro, que no deja de ser nunca un sujeto o un pueblo diferente, cuyo encuentro con la cultura occidental se tramita como una solución posible a su salvajismo, en un caso, o como la causa de un conflicto territorial, de salud y cultural, en otro.

Por último, tanto en Andujar como en Eckhout se reconoce la idea de promesa como aquello que vincula al presente con el futuro deseado: en el pintor, promesa de civilización a partir de ciertos atributos que devienen de la conquista europea y no de la propia cultura tapuia o tupí; en la fotógrafa, promesa de salvación y de remisión a un pasado remoto y sin contacto. Así, la fotógrafa y el pintor ofrecen una redención, aunque con signos opuestos: en el caso de Andujar, la liberación del avance occidental; en el de Eckhout, la liberación del salvajismo caníbal (en el caso de los tapuias), en pro de una civilización occidentalizante.

Finalmente, se observó que, en las obras de Andujar y de Eckhout, estas utopías se producen desde una relación de ajenidad -aunque en diferentes grados- respecto de los retratados, donde aparece el exotismo como lo no familiar, en el caso de Andujar, y más claramente como lo extraño, en el caso de Eckhout. La otredad está presente en las imágenes producidas por la fotógrafa y el pintor, a pesar de sus disímiles propósitos. Desde la modernidad, el etnocentrismo, específicamente el de naturaleza europea, no solo ha moldeado las formas de clasificar a los otros, sino también funcionó como procedimiento para producir visualidades, incluso cuando las metas de salvación, como en el caso de Andujar, estuvieran en el centro del trabajo con las imágenes. La investigación a partir de series, tomando como base las ideas de Warburg y de Didi-Huberman, ha permitido observar la efectividad de esta comparación para ver qué modalidades específicas adquieren estas visualidades cuando se trata de tiempos distintos, pero bajo un macroproceso histórico común.

\section{ReFERENCIAS BIBLIOGRÁficAS}

Acuña, C. y Arqueros, G. (2009, 2 de octubre). Aby Warburg y el devenir del método iconológico. Facultad de Artes, Universidad de Chile. https://www.uchile.cl/noticias/55065/aby-warburg-y-el-devenir-del-metodoiconologico

Ahmed, S. (2015). La politica cultural de las emociones. UNAM.

Almeida, R. H. (1999, mayo). Tapuio: Povos Indígenas do Brasil [Pueblo indígenas de Brasil]. Instituto Socioambiental. https://pib.socioambiental.org/pt/Povo:Tapuio

Andujar, C. (2009). Marcados. Cosac Naify.

Belluzzo, A. M. (1994). O Brasil dos viajantes: imaginário do novo mundo [El Brasil de los viajantes: imaginario del nuevo mundo]. Metalivros.

Boivin, M., Rosato, A. y Arribas, V. (Eds.) (2004). Constructores de otredad.Antropofagia.

Bustamante, J. (2008). Visiones del nuevo mundo. Nuevas aproximaciones a la representación gráfica de América y sus habitantes. Ensayo bibliográfico. Revista de Indias, 68(244), 141-156.

Chicangana-Bayona, Y. (2008). Os Tupis e os Tapuias de Eckhout: o declínio da imagem renascentista do índio [Los Tupis e los Tapuias de Eckhout: el declive de la imagen renacentista del indio]. Varia Historia, 24(40), 591-612. https://doi.org/10.1590/S0104-87752008000200016

Cicerchia, R. (2005). Viajeros. Ilustrados y románticos en la imaginación nacional. Troquel.

Costa, M. E. (2015). Imágenes migrantes del siglo XIX en Argentina y México: estampas, libros, álbumes litográficos. En M. De Rueda (Comp.), Revoluciones, apropiaciones y criticas a la modernidad. Itinerarios del arte moderno entre América Latina y Europa (1830-1945) (pp. 29-41). EDULP.

Cuartero, I. Á. (2004). Gentes de color, gentes de placer y otras rarezas: una aproximación a su estudio en la pintura europea y americana de los siglos XVII y XVIII. En Archivo Histórico Insular de Fuerteventura (Ed.), En torno a las Antillas hispánicas: ensayos en homenaje al profesor Paul Estrade (pp. 458-472). Archivo Histórico Insular de Fuerteventura. 
Dra. Ana Bugnone, et al. Imágenes del otro en Brasil. Un anÁlisis comparado de artistas en expedic...

Didi-Huberman, G. (2006). Ante el tiempo. Historia del arte y anacronismo de las imágenes. Adriana Hidalgo Editora $(\mathrm{AH})$.

Dos Santos, I. y Penaforte, A. S. (2017). Pelos olhos de Claudia Andujar: necropolítica e coetaneidade entre os yanomami. [A través de los ojos de Claudia Andujar: necropolítica y contemporaneidad entre los yanomami]. Revista Eletrônica de Estudos do Discurso e do Corpo, 11(1), 140-157. https://doi.org/10.22481/redisco.v11i1. 2491

Garramuño, F. (2016). Dimensiones de lo impersonal en la cultura contemporánea. Badebec, 5(10), 130-140.

Garramuño, F. (2017). Imágenes de sobrevida: figuraciones del pueblo yanomami en el arte contemporáneo. El Taco en la Brea, 2(6), 191-200.

Garramuño, F. (2018). La singularidad expuesta. Pueblos parcelados, potencias de lo impersonal. Revista Latinoamericana del Colegio Internacional de Filosofia, 3(1), 75-84. http://www.revistalatinoamericana-ciph.or $\mathrm{g} /$ wpcontent/uploads/2018/02/RLCIF-3-La-singularidad-expuesta.pdf

Grijalva, J. C. (2004). Vasconcelos o la búsqueda de la Atlántida. Exotismo, arqueología y utopía del mestizaje en "La raza cósmica". Revista De Crítica Literaria Latinoamericana, 30(60), 333-349. https://doi.org/10.2307/45313 51

Hernández, F. (2005). ¿De qué hablamos cuando hablamos de cultura visual? Educação y Realidade, 30(2), 9-34.

Kalinsky, B. y Pérez, G. (1993). De aquí y de allá: la ambigüedad etnográfica de la otredad. Iztapalapa. Revista de Ciencias Sociales y Humanidades, 13(30), 51-66.

Krotz, E. (2004). Alteridad y pregunta antropológica. En M. Boivin, A. Rosato, y V. Arribas (Comps.), Constructores de otredad. Una introducción a la Antropología Social y Cultural (pp.16-21). Antropofagia.

Mignolo, W. (2007). El pensamiento decolonial: desprendimiento y apertura. Un manifiesto. En S. Castro-Gómez y R. Grosfoguel (Coords.), El giro decolonial. Reflexiones para una diversidad epistémica más allá del capitalismo global (pp. 25-46). Siglo del Hombre Editores.

Mignolo, W. y Gómez, P. (2012). Estéticas decoloniales. Universidad Distrital Francisco José de Caldas-ASAB.

Mirzoeff, N, (2003). Una introducción a la cultura visual. Paidós.

Mirzoeff, N. (2016). El derecho a mirar. IC-Revista Cientifica de Información y Comunicación, 13(1), 29-65.

Moraña, M. (2012). Postcriptum. El afecto en la caja de herramientas. En M. Moraña e I. Sánchez Prado (Eds.), El lenguaje de las emociones. Afecto y cultura en América Latina (pp. 313-337). Iberoamericana / Vervuert.

Nancy, J. L. (2014). El arte hoy. Prometeo Libros.

Paredes, A. (2017). América Latina exótica: hermenéutica eco-estética de la naturaleza y el cuerpo. Una aproximación al tema [Tesis doctoral. Universidad Michoacana de San Nicolás de Hidalgo]. http://bibliotecavirtual.dgb.umich .mx:8083/xmlui/handle/DGB_UMICH/27

Parker, R. (2006). Visions of Savage Paradise: Albert Eckhout, Court Painter in Colonial Dutch Brazil [Visiones del paraíso salvaje: Albert Eckhout, pintor de la corte en el Brasil colonial holandés]. Amsterdam University Press.

Penhos, M. (2005). Ver, conocer, dominar. Imágenes de Sudamérica a fines del siglo XIX. Siglo XXI.

Pereira, V. L. (2015). Marcados, de Claudia Andujar: do documento visual à imagem poética [Marcados, de Claudia Andujar: del documento visual a la imagen poética] [Tesis de maestría. Universidade Federal de Uberlândia]. h ttps://repositorio.ufu.br/handle/123456789/12375

Quijano, A. (2000). Colonialidad del poder, eurocentrismo y América Latina. En E. Lander (Comp.), La colonialidad del saber: eurocentrismo y ciencias sociales. Perspectivas Latinoamericanas (pp. 201-246). CLACSO.

Ramos, A. R. (2016). Oro y epidemias entre los Yanomami de Brasil. Muestra de Claudia Andujar. Marcados. Conferencia llevada a cabo en el Museo de Arte Latinoamericano. Argentina.

Richard, N. (2014). Diálogos latinoamericanos en las fronteras del arte: Leonor Arfuch, Ticio Escobar, Néstor García Canclini, Andrea Giunta. Ediciones Universidad Diego Portales.

Ruvituso, F. (2019). Tensiones y supervivencias. Apuntes sobre la iconología de Aby Warburg. En R. Hitz, F. Ruvituso y J. C. Pedroni (Coords.), Historiografias del arte: debates y perspectivas teóricas (pp. 78-109). EDULP.

Said, E. (2007). Orientalismo. Debolsillo. 
Senra, S. (2009). O último círculo. [El último círculo]. En C. Andujar, Marcados (pp. 126-142). Cosac Naify.

Springborg, P. (1996). Orientalismo. En W. Outhwaite, y T. Bottomore (Eds.), Versión brasileña: R. Lessa, y W. G. Dos Santos (Ed.), Dicionário do pensamento social de século XX [Diccionario del pensamiento social del siglo XX] (pp. 541-543). Jorge Zahar.

Todorov, T. (1991). Nosotros y los otros: reflexión sobre la diversidad humana. Siglo XXI Editores.

Toscano, D. E. (2017). El cuerpo humano y el dispositivo expedición-conquista: un efecto de prácticas heterogéneas. Alpha, (44), 9-21. https://doi.org/10.4067/S0718-22012017000100009

Vries, E. D. (2002). Eckhout e o Novo Mundo [Eckhout y el nuevo mundo]. En E. Vries y G. Dourado (Eds.), Albert Eckhout volta ao Brasil/Albert Eckhout returns to Brazil [Eckhout vuelve a Brasil] (1644-2002). Catálogo da Exposição (pp. 155-165). Nationalmuseet.

Warburg, A. (2010). Atlas Mnemosyne. Akal.

\section{Notas}

1 Según Almeida (1999), el nombre Tapuia es más una expresión de identificación por otros habitantes de la región que una autoidentificación étnica.

2 Las particularidades del trabajo fotográfico de Andujar han despertado interés, tal como puede verse en los trabajos de Garramuño (2016, 2017, 2018), Dos Santos Neves y Penaforte (2017), Pereira (2015) y Ramos (2016).

3 Edward Said se refiere con 'orientalismo' a los estudios realizados sobre Oriente que construyeron una visión de esa parte del mundo como un otro respecto de Occidente, el cual aparecía como triunfante y civilizador (Springborg, 1996).

4 Se emplea el concepto de otro en masculino, en lugar de otro/otra para simplificar la lectura.

5 La antropología, inicialmente, consideraba la otredad como un otro radicalmente extraño, por ejemplo, el 'salvaje' y el 'indio'. Luego, fue incorporando otros grupos y sujetos como los pobres urbanos, las minorías étnicas y las diversidades sexuales. En el marco de los estudios etnográficos, tanto el 'nosotros' como el 'otros' son construcciones ficcionales que responden al trabajo de campo, pero que se articulan con relaciones efectivas. Para profundizar este tema, ver Kalinsky y Pérez (1993).

6 En neerlandés Vereenigde Oostindische Compagnie o VOC, literalmente, Compañía Unida de las Indias Orientales.

7 Pernambuco estuvo bajo dominio holandés entre 1630 y 1654.

8 La publicación en este artículo de las obras de Albert Eckhout cuenta con la autorización del National Museum of Denmark.

9 Las fotografías que componen esta serie pueden verse en https://www.inhotim.org.br/item-do-acervo/claudia-andujar/ y en https://malba.org.ar/evento/claudia-andujar-marcados/. 